\title{
ESTONIAN FAIRY TALES UP THE BEANSTALK INTO HEAVEN AND COAL PORRIDGE: TWO TALES OF GROWING UP
}

\author{
RISTO J ÄRV \\ Head of the Archives, PhD \\ Estonian Folklore Archives, Estonian Literary Museum \\ Vanemuise 42, 51003 Tartu, Estonia \\ e-mail: risto.jarv@folklore.ee \\ MAIRI KAASIK \\ Project Assistant, MA \\ Estonian Folklore Archives, Estonian Literary Museum \\ Vanemuise 42, 51003 Tartu, Estonia \\ e-mail: mairi.kaasik@folklore.ee
}

\begin{abstract}
The article focuses on two Estonian fairy tale types that have been recorded among the Orthodox Seto minority in the south-eastern corner of Estonia. In the index of Estonian folktales they have been described under tales of magic (fairy tales) as tale types Ee $328 \mathrm{C}^{*}$ and Ee $327 \mathrm{H}^{*}$. One of the tale types observed is a masculine folk tale (one with male protagonists), the other can be considered a feminine folk tale with female protagonists despite it seemingly having two main characters of different genders. In both tales the protagonists reach a hostile place after moving through liminality, and both tales can be interpreted as tales of growing up.

KEYWORDS: children's tale $\bullet$ folktale $\bullet$ tale of magic $\bullet$ Seto
\end{abstract}

Drawing on the corpus of folktale texts created by the Estonian Folklore Archives at the Estonian Literary Museum and the Department of Estonian and Comparative Folklore at the University of Tartu, our work group has compiled a two-volume typological anthology of Estonian fairy tales that includes representative text samples (EMj I-1 2009;

* The article was supported by institutional research grants IUT22-4 and IUT2-43 from the Estonian Ministry of Education and Research and by the European Union through the European Regional Development Fund (Centre of Excellence in Estonian Studies). The article is an amended version of a presentation made at the Storytelling, Story-dwelling: Home, Crisis, and Transformation in Fiction and Scholarship panel at the 13th SIEF Congress in Göttingen, Germany, March 26-30, 2017. The authors are grateful to the panel convenors Francisco Vaz da Silva and Nemanja Radulovic for their later comments. 
EMj I-2 2014). A great number of tale types represented in Estonia have approximate type equivalences in Europe, or, more narrowly, among the tale types known in the Baltic or Finno-Ugric regions. Yet there are also plots in Estonia that are idiosyncratic and not very widely spread. In Estonia, such tale types can most often be found in Setomaa. The present article discusses two such tale types that are known to have been described in this form only in Estonia - these are the tale types Up the Beanstalk into Heaven (Ee $328 \mathrm{C}^{*}$ ) and Coal Porridge $\left(\mathrm{Ee} 327 \mathrm{H}^{*}\right)$. With a couple of exceptions these tales have been recorded only among the Russian Orthodox Seto people in south-eastern Estonia. For a brief overview of Seto fairy tales, see Salve and Sarv 1987: 198-199.

It is likely that the tales are very old. In her overview of the Seto repertoire, the Estonian folklorist Kristi Salve (Salve and Sarv 1987: 15) emphasised that the plot of Coal Porridge is definitely one of these "typologically clear tales, even though they may share motifs with other fairy tales":

The purely Seto fairy tales have a number of features in common with tales from the Baltic-Finnic and the Baltic group. The events of both take place during some mythical prehistoric time [vana ilma aig, 'in the time of the olden world'] in an archaic agrarian setting, with little differentiation between good and evil. The most important human relationships in these tales are those between a brother and sister. (Ibid.)

Both versions of the tale types in the Estonian Folklore Archives derive from the oral tradition; thus it can be claimed that they are not literary retellings, but manuscript recordings from among those 'common people' who have participated in the folklore process since the beginning of folklore collecting in Estonia (cf. Järv and Sarv 2014: 50-52). Most of the recordings have come from ordinary contributors to folklore collecting campaigns since the 1880s. Where the storytellers have given the tales titles of their own, these have been used, for instance Up the Beanstalk or Mother and Son (in the following, the title Up the Beanstalk will be used); A Fairy Tale about a Brother and Sister, or Sister at the Old Sin's. English translations of archival versions of each folktale can be found in the collection Estonian Folktales: The Heavenly Wedding (Päär and Türnpu 2015 [2005]). Its compilers, Piret Päär and Anne Türnpu (ibid.: 87-92; 110-115), have given these stories the titles Hut in the Heavens and Coal Porridge. A version of the former tale has also been published in the Deep in the Forest collection (Järv 2018: 281-287) under the title given to it by the storyteller, The Little Boy in the Goat House.

Some versions of the tale types are more recent audio or video recordings from fieldwork expeditions made to Setomaa in the 21st century. The recent archival versions have been influenced to a degree by the published version of the stories Up the Beanstalk and Coal Porridge from a collection called The Cluster of Berries and Other Seto Folk Tales (Marjakobar ja teisi setu muinasjutte; first published in 1959, reissued in 1989, third edition in 2015), which themselves are based on earlier archival versions. Thus, this collection of tales has influenced versions recorded since 1959.

The article consists of three parts: first, a survey of two tale types and similar typological units in Estonian folk tales is given; this is followed by an analysis of the characters' movements in the tale types; and finally an attempt is made to interpret the tale types proceeding from the question of meaning and interpretation from a comparative (allomotific) perspective. 
In the Up the Beanstalk into Heaven (Ee 328C*) tale type, the son of a poor woman climbs up a beanstalk into heaven and discovers a wonderful heavenly house that is edible. The building materials may include baked goods (black bread, white bread, barley cakes, gingerbread), and milk products (curd, cheese; on one occasion there is even a house made of butter), as well as sugar doorframes. For example: "There was a beautiful house. The house had benches made of pancakes, a stove made of bread, a ceiling made of biscuits, walls made of sweet pastry - all sorts of things like that." ${ }^{1}$ The descriptions of the house often contain alliteration "piirakotsõ pingi' ja saiadsõ saina"' ('benches of pies and walls of white bread'). In later recordings sweets and chocolate are mentioned - "The palace was made of gingerbread, sweets and chocolate". ${ }^{2}$

The edible house can be seen as an indirect parallel to that in the Grimms' fairytale Hänsel und Gretel (ATU 327A). The heavenly house and its various appetising furnishings represent wish fulfilment in the context of the poverty of the peasant household. The boy eats to his heart's content and hides behind the oven. The unusual inhabitants of the house, who are characterised by a number of eyes that differs by one for each being (for example, many-eyed goats) keep watch one after the other, yet the boy lulls them to sleep with a song.

$\begin{array}{ll}\text { Uinu, uinu, üks silm, } & \text { Close, close, one eye, } \\ \text { uinu otsani magama! } & \text { close and sleep! } \\ \text { Uinu, uinu, teine silm, } & \text { Close, close, the second eye, } \\ \text { uinu otsani magama! } & \text { close and sleep! }\end{array}$

The hero repeatedly sings to his many-eyed adversaries in order to put them to sleep. On the last occasion he does not notice, however, that one eye of the being with the greatest number of eyes has remained open. (If this is understandable for a three-eyed character, with songs to a multi-eyed being, the answer to the question of how and why the boy fails to notice can be left to folktale logic.) So in the end the boy gets caught and is cast out of heaven to his home (although in some versions he can stay in heaven).

Because the tale type has an extremely variable plot that incorporates types from other folktale categories, the inhabitants of the heavenly house differ in different variants. Generally they are many-eyed goats, but also other characters can occur, such as labourers, guardians, masters of the house, fairies, and, in a recent text, even dwarfs. In a version from 2006 the storyteller does not specify who exactly lives in the house. When questioned, she explains that they are neither animals nor old devils, but "kind of like people, but not of our sort, with three eyes". ${ }^{4}$

The boy who lulls his adversaries and destroys the furnishings by eating them resembles a trickster, and this part of the tale is similar to trickster-tales or carnivalesque tales (cf Jason 1977: 40-41). The dwellers of the house do not seem to be dwarfs with a friendly disposition towards the hero, as in tale type ATU 709, but emerge more or less as menacing enemies, even though they might appear to be cute little goats. This is confirmed by the ending of the story in which the solutions of the plot differ as to how the inhabitants of heaven treat the person who has been vandalising their home - often he is beaten and cast down from heaven, but in quite a few cases the goats ask him to become their master. There are various versions of the boy's subsequent fate, such as: 
the boy is cast down onto earth (to his death); the boy is sent to earth to fetch his mother who falls to her death (together with the boy); the goats invite him to be their master or goatherd; the boy flees from heaven using the beanstalk, cuts it down and thus escapes his pursuers; or the boy is given a treasure and a young wife and is sent back to earth. A slight increase can be detected in recent times in the number of tales that tend to have a favourable ending in store for the hero.

The earliest recording of the tale comes from Tõstamaa parish from 1893 (also published in Ussi naine 2014: 57-58). A significant share - a full quarter of the archival recordings (12 versions) - of Up the Beanstalk were recorded between 2004 and 2006 when there were folklore expeditions to Setomaa that particularly focused on fairy tales. There are 62 variants of the tale type, mainly deriving from the Seto areas. With very few exceptions, almost all the storytellers of Up the Beanstalk were women.

Regarding such tales as ATU 327A (Hansel and Gretel), Bengt Holbek (1987: 160$161,630)$ has remarked that, even though they are listed as fairy tales in the type index, they are rather examples of the so-called children's fairy tales that, in contrast to ordinary fairy tales, do not end with weddings. This seems to be confirmed by the repeated, and increasingly lengthy, singing of lullabies, which is why the fairy tale can be well suited as a bedtime story.

In the Coal Porridge (Ee $\left.327 \mathrm{H}^{*}\right)$ tale type a brother and a sister who have been left home on their own make coal porridge. The cryptic notion of coal porridge has ambiguous content and there are no parallels to it in Estonian food culture. (In the two variants the children make ash porridge instead.) Although it seems rather unpalatable at first, the children still seem to like it, as they look forward to making it - thus it may be something special or extraordinary. They are punished for this - the sister is smeared with coal and becomes black and dirty. Thus, the result is certainly ominous and she has to be left in water to soak.

The boy takes her outside to soak in water and later sings too her:

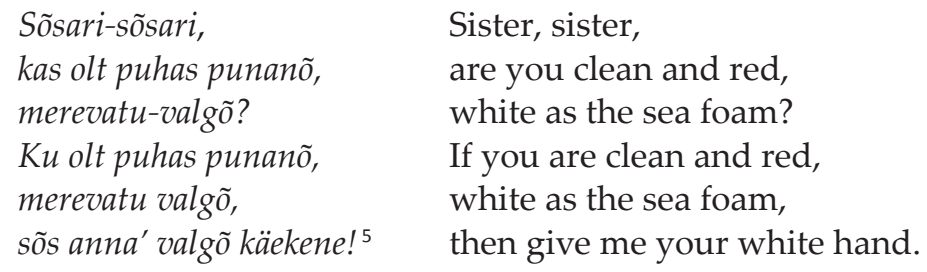

The devil lures the girl into his dwelling, which lies further off, often in the woods. The boy finds them and sees the sister engaged in housework with the devil, yet in contrast to the Faithless Sister (ATU 315) tale type the sister is still favourably disposed towards her brother. The following is sung when the boy informs his sister that he has come to her window and is trying to contact her, describing the situation:
Kuri tege reke,
Evil makes a sledge,
kõgistõllõs kõdaret, mino sõsar näütäs tuld. ${ }^{6}$
[evil] shapes the spokes, my sister holds the light.

Instead of the devil there might be an old wolf as the vanasusi (also used in folk tradition as a euphemism for the devil): 
Sõsar kast leibü, vanasusi reke tege.
Sister is kneading bread, the old wolf is crafting a sleigh.

The boy plays dead, and by using this ploy the pair succeed in overcoming the devil. When the girl finally learns from the singing that her brother has come to fetch her, making ale for the funeral of 'the dead brother' follows. The description of the beer making is ethnographically correct and true to life - for example, it used to be boiled in a wooden vessel with the help of hot stones. Here, only the vessel is different, as the devil's stomach or some other, less refined body parts of his are used for this purpose. In this, the actions in the fairy tale parallel reality.

There are 17 recorded variants of this tale type, which in terms of Estonian tales of magic is rather a small number, compared to the most popular types - ATU 313 The Magic Flight with 265 variants, ATU 480 The Kind and the Unkind Girls with 234 variants, and ATU 300 The Dragon-Slayer with 220 variants (cf. data from EMj I-1 2009).

Although it may seem that the brother and the sister are both protagonists in this tale - the brother even seems to be more active - the girl's central role in the plot indicates that she is the main protagonist. All the known tellers of these tales have been women, and based on Estonian material we can claim that male informants prefer telling stories with male protagonists. This is especially noticeable in fairy tales recorded in the 19th century. Perhaps women informants prevail because the variants of the Coal Porridge tale type were recorded later, after women had become the main transmitters of the fairy tale tradition in Estonia (cf. Järv 2005: 50-51).

The survey article on the Estonian folktale tradition in Enzyklopädie des Märchens refers to the Coal Porridge tale type when dealing with the Seto material, highlighting it as a particular example not classifiable as any other known tale type (Masing 1984: 483). Proceeding from several characteristics we have nevertheless classified both types as fairy tales (tales of magic) in the Estonian typology. Coal Porridge was placed close to Hansel and Gretel (ATU 327A) due to its resemblance to the well-known tale of the escaping brother and sister. This is why type number 327 is followed by the first hitherto unused alphabet character in the type index, Ee $327 \mathrm{H}^{*}$. In a similar manner, the Up the Beanstalk tale type has been placed close to the Jack and the Beanstalk tale type (ATU 328A according to the international type index) the uniting factor being a poor boy who climbs a beanstalk into the sky.

In a similar Lithuanian tale type, the girl is born dirty, black or dark; in the Estonian type, the girl becomes sooty after cooking coal porridge, or after her brother pours the porridge over her. Then, in both traditions, the female protagonist is taken to the sea to wash and becomes clean and beautiful again, after which the antagonist appears - a wolf in the Lithuanian type, and an archaic creature called vanahalb ('the Old Evil One') or tikõveline ('the Vicious Brother') in the Estonian type (see further Salve and Sarv 1987: 12). Two Lithuanian variants have been published in German in the anthology Litauishce Volksmärchen (LVm 1982: 81-87, classified as cf. AT 123 and AT 703*+702B*). Kristi Salve (2006: 349) considers Lithuanian and Estonian (Seto) versions to be different redactions of the same type, or even parallel types. She points out the important difference in the Lithuanian variants. The first is that the sister has been black since birth, the second that the last scene (the mother's wake) takes place at her home with the wolf perishing in a fiery hole (ibid.: 349-350). 
It is worth noting that one of the earliest Estonian recorded variants of Coal Porridge (1927) is very similar to the Lithuanian type in that the brothers have a black sister from the beginning:

Once there were a sister and three brothers. The brothers were all handsome boys, but the sister was very black. So they wished that their sister were as clean as they were, and took her to the flax hole to soak. ${ }^{8}$

Another similar tale type is Rescue by the Brother (ATU 312D, the title in the Estonian typology is The Devil Leads the Sister Astray), in which the devil lures the sister from the brothers to his own household. In that type, the sister also does chores in the devil's house - for example kneading dough (EMj I-1 2009: 593). With the help of animals, the brothers manage to kill the devil and save their sister. The girl, who works as a housekeeper or a housemaid for an ogre, appears in several types: among others in The Magic Flight (ATU 313), and Sister Turned into a Cuckoo (Ee 720*).

\section{MOVEMENT AND DWELLINGS IN THE FAIRY TALES}

Often, the starting point of a folktale plot is the home. In The Morphology of the Folktale, Vladimir Propp (2003 [1928]: 50) points out as Function No 11: "The hero leaves home", thus entering the main events of the tale. Heda Jason (1977: 199-200) indicates that relative to each other, the human world and the fairy tale world can be located on a horizontal or vertical axis (on movement between the human world and the otherworld in Estonian fairytales, see also Kaasik 2013). In these tales the journey unfolds horizontally (in Coal Porridge) or vertically (Up the Beanstalk), respectively.

It is the houses and the movement that starts from them that launch the tales. In Up the Beanstalk the main movement occurs vertically, although the boy's movement back and forth between the house and the sauna when he constantly reports how the bean is growing to his mother occurs on the everyday, horizontal level. The sauna is the building from whence the vertical movement starts, and when the boy reaches heaven, occasionally a couple of words are dedicated to his walking in the sky, on the clouds; in this plot segment there is another short-term horizontal movement.

At the beginning of Up the Beanstalk, the home of the mother and her son is dominated by the sauna. In Estonian peasant culture the sauna was situated separately from other buildings, at a distance from them (cf Paulson 1971: 160-162). The sauna was of crucial importance in the human life cycle: women gave birth in the sauna and corpses were washed there. Considering this, as well as more general belief-related customs, it can be claimed that in Estonian peasant culture the sauna was a liminal space located between the home and the unholy-supernatural world, in the 'in between' space, to use Jason's (1977: 190) term. Against this background it is understandable that at certain times (at midnight for example) the devil could be met there. There is a popular Estonian tale type in which an orphan remains in the sauna at midnight on a Thursday and the devil comes to woo her (ATU 480A, Girl and Devil in a Strange House, Estonian name Devil Wooing in the Sauna). It is under the sauna bench that the boy plants the bean that will grow tall enough to go through the roof and up into the sky. It is significant that in all Estonian versions of the tale the bean grows gradually. In her survey 
Christine Goldberg (2001: 16) finds "incremental repetition" in American texts, something that can be observed in this tale. The extremely tall beanstalk can be considered a liminal place, a bridge between this side and the other, an in between space. The motif of the beanstalk can be interpreted as the biblical Jacob's ladder to heaven or the mythical world tree that connects heaven and earth (see Kaasik 2014: 66). In Estonia, climbing up the beanstalk has occasionally been described as a long journey.

When the hero reaches heaven having climbed the beanstalk he comes to another place, a marvellous house. The house contains rather ordinary and simple pieces of furniture (a table, chairs, a bed) and a stove, all of which could be found in any peasant home. What is important is that the house is miraculous as it is gastronomically valuable. An edible heavenly dwelling is a dream come true for a peasant, who will have experienced food shortage (compare it with the dream of Paradise in the Estonian folk tradition, where one can sleep between two fur coats and dunk solid fat in liquid fat).

The plot hinges upon the stove because the protagonist can hide from the inhabitants of the heavenly house behind it. Occasionally he takes along a hunk of bread broken off from the table when he hides. The heating stove has a central position in the house. It is described as built of white bread, curd, bread, cottage cheese, barley cakes, or gingerbread.

In Coal Porridge, movement occurs horizontally, although the journey from the sea to the devil's house seems to unfold in a different space or in a supernatural space on a level other than that of the trip from the home to the sea.

The home has a central place in triggering events, as it is the initial situation. A brother and a sister are home alone, which gives them the opportunity to eat coal porridge in secret. The home itself is given virtually no description; rather it presents an ordinary farm milieu that the brother and the sister have been left to take care of. The farm is an everyday environment familiar to storytellers and audiences alike and thus does not merit a more detailed description.

The liminal space is the seaside - there is no sea in Setomaa but the large Lake Peipsi has also merited this name. Even this 'platform' can be considered an in between space comparable to the beanstalk in the previous tale. In two versions, the house of the devil is located in or beside a forest (an old woman, a fairy tale helper, suggests walking "along the edge of the forest until you reach the devil's house ${ }^{\prime 9}$ ). Curiously enough, no text mentions the house being under the ground, which is extraordinary considering the location of hell as the devil's usual abode. At the same time it could be linked to those Seto folktales that tell of "the time of the old world" when Christians and devils lived together on earth, and even intermarried (for example, see Seto tale type Ee 327J* The Devil as the Father).

The descriptions of the devil's house itself are rather concise, and usually just the arrival at the house is described. Similarly to the heavenly house (excepting its building materials) the devil's abode is fairly ordinary and is by no means different from a normal farmhouse, in addition to which the activities that are carried out there are normal, everyday ones. Having devils live in a way that resembles the ordinary daily life of humans occurs in other Estonian folktales as well. In some cases even a time period when "the demons lived among people" is mentioned. Thus people and supernatural characters often share a mutual space and the extraordinary is not always differentiated from the ordinary (the difference rather becomes clear through human and supernatural activity in tales). 
Thus, the description goes: "[The three brothers] reached a house and looked in through the window; they saw the Evil One who was making a sleigh in the farmhouse and the sister was kneading bread dough in the corner." ${ }^{10}$ Here, in the devil's house the girl "starts to learn the lore of adult life that will be expected of her" (cf. Snow White in the house of the dwarfs, Girardot 1977: 290-291). She was a child only recently, but now she is practicing to take on the role of a mature adult. Goldberg (2004: 310) has suggested that the heroine in the house of the kidnappers has an ambiguous charactershe is part of the villains' household, but is not loyal to them. Thus it might be possible to suggest that even in this tale type the sister is simply growing up while staying with the devil.

In a way both tale types are connected with cleansing. In Up the Beanstalk, the sauna plays a part in triggering the events as a building designated to washing from which the marvellous plot starts to unfold. The extremely tall beanstalk that has sprouted from under the sauna bench makes it possible to climb to the upper world. In Coal Porridge the sister is taken to the sea or lake to wash so that she may become clean, allowing the Evil One to deceive her. Only afterwards does his house come into play. In addition to this it is worth mentioning that in both tale types it is something edible (coal porridge or the house of the goats/robbers) that leads to subsequent action.

The in between space ends at the window in both stories. The boy begins to observe the activities of his sister and the devil through the window, a motif that is repeated in different versions and emerges as the main way in which the boy sees the devil. The window marks the differentiating or separating spatial boundary between the brother who is outside and the devil and the sister who are inside.

From the point of view of the tale it is important that the plot is developed through multiple sets of dialogue (the growing of the bean plant in Up the Beanstalk; the process of the sister becoming clean in Coal Porridge). Repetitive dialogue and songs containing few changes indicate the long and continuous duration of both processes.

\section{N T ER PRETATION}

The tellers or recorders of both tale types have not opened up the context to any significant degree. What follows is an attempt to offer a comparative interpretation of the two tales proceeding from the plots. We do not rely on a single literary version, as has often been the case when performing psychological analysis; rather, as folklorists we draw on multiple variants (cf. also Dundes 1989 [1987]: 119). Here, the variability of the variants stored in the archives can be of help. As there are several versions, analysis of the variations and the symbols in them can be facilitated by what Alan Dundes (1987 [1980]: 176) has called allomotifs - motifs that fill the same structural slot and are therefore equivalent.

Let us start with the interpretation of Up the Beanstalk. Because the comparable tale Jack and the Beanstalk is widely known, there have been several different interpretations of it, for example introduced by Anna E. Altmann and Gail de Vos in the chapter "Jack and his Stories" in Tales, Then and Now (1999). Several researchers have also favoured a Freudian interpretation recounting the fairy tale as a parable of a young man's sexual self-discovery. This could be corroborated by the fact that, despite dead 
ancestors being generally respected in folk tales, several versions of Up the Beanstalk see the boy treating his mother, who falls down the beanstalk, rather disrespectfully (cf. the folk tale example in Järv 2018: 282). This could also support the 'growing up' interpretation.

The children's psychologist Bruno Bettelheim (1991 [1976]: 190, 192) contends that "in fairy-tale fashion" the tale describes "the stages of development a boy has go through to become an independent human being" and thus, the plot "could teach parents much as it helps children grow up".

The hero leaving his home and climbing to heaven makes an adventurous tale about a young man growing up possible. Here, the marvellous fairy tale setting - the heavenly house that has edible walls, furniture and other utensils - occupies an important place. If we put ourselves in the shoes of a peasant who had to make do with insufficient daily fare, the mental transfer to a rich setting of fine food could offer some compensation, even if this was only imaginary. However, the hero's greed is ultimately punished demonstrating that certain restrictions must be observed when one becomes an adult.

Thus, although the tale does not turn into a wooing story of a hero who has left his home, as with the classic The Dragon Slayer (cf. Propp 2003 [1928]; also Vaz da Silva 2000; Järv 2003), it represents a story of the time that inevitably precedes the wooing, i.e. the period of the hero's maturation. It can be claimed that Up the Beanstalk is not an ordinary career story as usually found in fairy tales; instead, it talks of wish fulfilment and sating one's desires, with the resulting punishment.

The question remains as to whether Coal Porridge, featuring a brother and a sister, is a simple innocent children's fairy tale in the sense of Holbek (1987: 160-161) (and as given above), as the children's experimental cooking is not followed by a wedding, as is characteristic of fairy tales.

First, there is the question of whether the tale is masculine or feminine. Is the brother the girl's helper (as in the first part of the tale) or is the sister the boy's helper (as in the second part, under the devil's window)? We are suggesting a different interpretation, which is that they cooperate, with the main character being the girl.

An archival text speaks of the siblings returning home: "The brother and sister were very glad to be rid of the devil; they left everything and went home. At home they lived long and got on very well with each other." 11 This is a derivation of the standard final chord of fairy tales, a forward-looking connection of two characters of the opposite sex. In one version, the youngest of the brothers marries the sister. ${ }^{12}$ However, their remaining together need not be seen as an incestuous solution, rather as their occupying the same role.

When observing allomotifs in such a way we can also consider a literary rewriting of Up the Beanstalk that is based on a popular variant in which a boy and a girl climb up the beanstalk together. Ansomardi (1911: 6) - the pen name of Peäro August Pitka interpreted the tale as follows in an early published literary version:

First Janni, then Manni following him, the children started to climb. By noon they had climbed more than half of the way. They stopped for a while, ate peas from some pods to quench their hunger, and went on. 
Similarly, both of them are found and cast down:

Shouting out loud, the goat people sprang to the stove and pulled Janni and Manni from behind by their legs. A goat person grabbed the hands of each child, while a third pushed them with its horns; the rest were hopping around them delivering blows from the side. So Janni and Manni were quickly taken out of the room with much noise and shouting and dragged away across the plain up to a hole in the cloud. Then the goat people gave the children several painful pokes in the back that were so strong that they fell from the cloud one after the other like bundles of straw from the loft. (Ansomardi 1911: 9)

Ansomardi is not alone in offering this version. An archival variant brings together Up the Beanstalk (or, to be more exact, a reminiscence of its plot) and Coal Porridge. ${ }^{13}$ In this version a brother and sister first climb up the beanstalk, taking their mother with them in a bag; the mother falls down and dies and both children return. They start to arrange the mother's funeral and the girl is smeared with coal porridge. The boy rescues her in the traditional way.

An interpretative option based on the notion of the home can be offered. Proceeding from Axel Olrik's (1992 [1921]: 51; §73) epic law of twins, when two characters perform an action jointly, "they are both depicted weaker than a single character". In the case of Coal Porridge, the brother and sister, similarly to the brother and sister in Hansel and Gretel, have been described as 'weaker' because together they fulfil the role of one person.

Thus, although one of the tales is masculine and the other has two protagonists, they can be compared to each other. In addition to looking for allomotifs from other version, a comparison of the two plots might also prove useful in trying to find the meaning of the tales. In both tales, the characters go to a place inhabited by characters who lie outside the social order that resembles the mythic beginning of time, similar to the tale of Snow White (cf. Girardot 1977: 290).

In the case of Coal Porridge, the siblings merge, or at least are merging, to become one person. This can be seen when, despite the brother not telling his sister what to do when he pretends to be dead beside the devil's house, she enters the scenario using her own initiative.

Colours can be useful when trying to give a symbolic interpretation to a tale, as symbolism can be expressed through colours as well actions. While no colours are mentioned in Up the Beanstalk, Coal Porridge features memorable and intense colours such as red, black and white. Black is not always mentioned explicitly, yet can be deduced from the colour of coal; the other two occur repeatedly in a song refrain. This chromatic trio has been related to the image of femininity in the Snow White tale type (ATU 709) by Fransisco Vaz da Silva (2007: 249). Vaz da Silva (2015), among others, has employed this approach when analysing the occurrence of three colours in The Maiden Who Seeks her Brothers (ATU 451) tale type.

The Estonian folklorist Kärri Toomeos-Orglaan (2016: 45), who has discussed the topic of colour in fairy tales, has interpreted the sister's turning black as her demonisation or even death. This interpretation is supported by the following development of the story according to which the devil takes the girl, who has been left to soak in the water, with him. Thus it may seem that the greyness (or blackness) of ashes or coal 
stands in contrast to the purity and innocence of the female protagonist; specifically, when she turns grey she starts attracting the black devil.

Isabel Cardigos (1996: 128-129) has described fairy tales in which the heroine is thrown into the sea to live for a while and "restored to health", comparing the sea with a "realm of periodity and renewal". In these tales, the heroine is either associated with blindness or black colour and this can be interpreted as enchantment at puberty.

The role of colours in the tale reveals something particularly remarkable when the brother asks his sister, among other things, whether she is "red" enough:

\section{Sõsarõni, sõsarõni, kas olt puhta, punanõ? \\ Sõsarõni, sõsarõni, kas olt merevatu valgõni?}

\author{
My sister, my sister, \\ are you clean, red? \\ My sister, my sister, \\ are you white as sea foam?
}

Visibly is also the connection with tale type ATU 333, in a variant where instead of the devil a wolf appears: "the wolf heard that the sister was singing at the ditch, and on the third morning he started to sing". At the end of the tale, which resembles Little Red Riding Hood (ATU 333), the wolf's stomach is cut open and the sister is retrieved.

According to the interpretations of child psychologist Bettelheim (1991 [1976]) and folklorist Holbek (1987), the little girl in a red cap wandering on her own symbolises her contacts with the dangerous 'wolves in society' because, in Charles Perrault's original rendering from 1697 (Perrault 1999 [1697]), the little girl's death highlights the moral in the story.

Closer investigation of some Lithuanian variants helps us understand the role of the mother. In these variants it is the mother who instigates the purification of the girl and later also saves her from the ogre (wolf). The girl's name in some Lithuanian variants is Aguonèe, meaning poppy and in one Jungian reading of the tale, parallels have been found between the development of a plant and the girl (Knabikiene 2001: 52). The girl can also be rescued by her mother, or put another way the girl adjusts to her role in society with the help of an older or more mature family member.

Thus it becomes increasingly more certain that Coal Porridge is a feminine folk tale about the sister growing up. Her maturation is symbolised by her becoming black and being kidnapped by the devil. These events happen to her and not to her brother(s), which shows it is gender specific. So, if we bear in mind that all the tellers of Coal Porridge have been female, the tale is not only what Holbek calls a "children's fairy tale" about misbehaving children, but is also a cautionary tale about becoming a mature person. Many studies (cf. Verdier 1997 or Vaz da Silva 2017) prove that although these 'children's tales' are devoid of sexual imagery, sexuality it still implicit in them.

We are aware that "One must never 'explain' to the child the meanings of fairy tales" (Bettelheim 1991: 155) and that the explanations proposed serve as one possibility, i.e. as a framework. Folk tales have no universal meanings, rather, meanings are actualised by the teller, recorder, listener or reader in the respective processes they all go through. The explanation proposed will provide a framework for situating the folk tale in a lived context. We also hope to have shown that, while there are differences between Up the Beanstalk and Coal Porridge, they still correspond to the development patterns of the hero and heroine in folktales. The above discussion confirms that it is problematic to rely on a single canonical variant when interpreting tales; rather, it is useful to observe 
different variants and variants arising among different peoples. In addition, analysing a tale type by viewing it through a slightly different but related tale type can also reveal possible meanings.

\section{NOTES}

1 RKM II 51, 42/52 (12) < Seto region, Mikitamäe commune, Usinitsa village - Veera Pino < Irina Pino (1949). Translation from Järv 2018: 282.

2 ERA, DH 1649 (7) < Seto region, Võru county, Värska town - Inge Annom, Mairi Kaasik < Veera Hirsik (2014).

3 S 44724/38 (15) < Seto region, Vilo commune, Molnika village - Viktor Ruusamägi < Usta Lohk (1932).

4 ERA, DV 599 < Seto region, Võru county, Värska town - Risto Järv, Reeli Reinaus < Anna Kullimaa (2006).

5 ERA, MD 99 (24) Tartu city < Seto region, Pankjavitsa commune, Kuurakõstõ village - Risto Järv, Merili Metsvahi, Kristina Veidenbaum < Ksenia Müürsepp (2001).

6 ERA II 174, 609/12 (17). < Seto region, Järvesuu commune, Podmotsa village - Aleksei Tubli $<$ [his grandmother] (1937). Translation from Päär and Türnpu 2015 [2005]: 113.

7 ERA, MD 99 (24). See Note 5.

8 S 2862/6 (9) < Seto region, Vilo commune, Alaotsa village - Mihhail Pihlapuu < Nadesda Liivapuu (1928).

9 ERA II 175, 51/5 (324) < Seto region, Järvesuu commune, Podmotsa village - Nikolai Sõrmus $<$ A. Adra (1937).

10 S 21619/28 (1) < Seto region, Vilo commune, Alaotsa village - Mihhail Pihlapuu < Anna Luikpere, heard the tale from her grandmother (1930).

11 S 21619/28 (1). See Note 10.

12 S 2862/6 (9). See Note 8.

13 ERA II 296, 215/21 (6) < Seto region, Vilo commune, Truba village - Aleksei Saar < Maria Saar (1941).

\section{SOURCES}

Folklore collections at the Estonian Folklore Archives of the Estonian Literary Museum:

ERA - Folklore collection of the Estonian Folklore Archives (1927-1944)

ERA, MD - Folklore collection of minidiscs of the Estonian Folklore Archives (2003-...)

ERA, DV - Folklore collection of digital videos of the Estonian Folklore Archives (1957-...)

RKM - Folklore collection of the Department of Folklore at the Estonian Literary Museum (1945-1994)

S - Setu folklore collection of Samuel Sommer (1922-1936)

\section{REFERENCES}

Altmann, Anna E. and Gail de Vos. 1999. Tales, Then and Now. More Folktales as Literary Fictions for Young Adults. Englewood, CO: Libraries Unlimited.

Ansomardi. 1911. Lastejutud. Tartu: Postimehe kirjastus. 
ATU = Uther, Hans-Jörg. 2004. The Types of International Folktales. A Classification and Bibliography. Based on the System of Antti Aarne and Stith Thompson I-III. Folklore Fellows' Communications 284-286. Helsinki: Suomalainen Tiedeakademia.

Bettelheim, Bruno. 1991 [1976]. The Uses of Enchantment. The Meaning and Importance of Fairy Tales. London: Penguin Books.

Dundes, Alan. 1987 [1980]. The Symbolic Equivalence of Allomotifs in the Rabbit-Herd (AT 570). - Parsing through Customs. Essays by a Freudian Folklorist. Madison, WI: University of Wisconsin Press, 167-177.

Dundes, Alan. 1989 [1987]. The Psychoanalytic Study of the Grimms: “The Maiden Without Hands" (AT 706). - Folklore Matters. Knoxville, TN: University of Tennessee Press, 112-150.

EMj I-1 2009 = Järv, Risto; Mairi Kaasik and Kärri Toomeos-Orglaan, comps. and eds. 2009. Eesti muinasjutud I:1. Imemuinasjutud. Monumenta Estoniae Antiquae V. Tartu: Eesti Kirjandusmuuseumi Teaduskirjastus.

EMj I-2 2014 = Järv, Risto; Mairi Kaasik and Kärri Toomeos-Orglaan, comps. and eds., Inge Annom, ed. 2014. Eesti muinasjutud I:2. Imemuinasjutud. Monumenta Estoniae Antiquae V. Tartu: Eesti Kirjandusmuuseumi Teaduskirjastus.

Cardigos, Isabel. 1996. In and Out of Enchantment: Blood Symbolism and Gender in Portuguese Fairytales. Folklore Fellows' Communications 260. Helsinki: Suomalainen Tiedeakademia.

Girardot, Norman J. 1977. Initiation and Meaning in the Tale of Snow White and the Seven Dwarves. - Journal of American Folklore 90 (357): 274-300. DOI: https://doi.org/10.2307/539520.

Goldberg, Christine. 2001. The Composition of "Jack and the Beanstalk". - Marvels $\mathcal{E}$ Tales 15 (1): 11-26. DOI: https://doi.org/10.1353/mat.2001.0008.

Goldberg, Christine. 2004. At the Ogre's House. - Folklore 115: 309-320. DOI: https://doi.org/10.1 080/0015587042000284284.

Holbek, Bengt. 1987. Interpretation of Fairy Tales. Danish Folklore in European Perspective. Folklore Fellows' Communications 239. Helsinki: Suomalainen Tiedeakademia.

Jason, Heda. 1977. Ethnopoetry - Form, Content, Function. Forum Theologiae Linguisticae 11. Bonn: Linguistica Biblica Bonn.

Järv, Risto. 2003. The Three Suitors of the King's Daughter: Character Roles in the Estonian Versions of The Dragon-Slayer (AT 300). - Folklore. Electronic Journal of Folklore 22 (20): 33-48. https://www.folklore.ee/folklore/vol22/dragons.pdf (accessed May 7, 2018).

Järv, Risto. 2005. The Gender of the Heroes, Storytellers and Collectors of Estonian Fairy Tales. - Folklore. An Electronical Journal of Folklore 29: 45-60. https:/www.folklore.ee/folklore/vol29/ gender.pdf (accessed May 7, 2018).

Järv, Risto, comp. 2018. Deep in the Forest. One Hundred Estonian Fairy Tales About the Forest and its People. Tallinn: Varrak.

Järv, Risto and Mari Sarv. 2014. Estonian Folklore Archives. From Regular Archives to Digital Archives. - Corpora ethnographica online: Strategien der Digitalisierung kultureller Archive und ihrer Präsentation im Internet, edited by Holger Meyer, Christoph Schmitt, Stefanie Janssen and Alf-Christian Schering. Münster u.a.: Waxmann, 49-60.

Kaasik, Mairi. 2013. A Mortal Visits the Other World - the Relativity of Time in Estonian Fairy Tales. - Journal of Ethnology and Folkloristics 7 (2): 33-47.

Kaasik, Mairi. 2014. [Chapter] III. - Ussi naine. Tartu: EKM Teaduskirjastus, 66-67.

LVm 1982 = Kerbelytė, Bronislava. 1982. Litauische Volksmärchen. Berlin: Akademie-Verlag.

Knabikienè, Gina. 2001. Archetipiniai mergaitės iniciacijų vaizdiniai lietuvių pasakoje „Aguonèlè”. - Liaudies kultūra 2: 49-52.

Marjakobar 1989 [1959] = Normann, Erna and Herbert Tampere, comps. 1989 [1959]. Marjakobar ja teisi setu muinasjutte. 2nd edn. Tallinn: Eesti Raamat.

Masing, Uku. 1984. Esten. - Enzyklopädie des Märchens 4, edited by Kurt Ranke and Hermann Bausinger. Berlin; New York, NY: Walter De Gruyter, 479-491. 
Olrik, Axel. 1992 [1921]. Principles for Oral Narrative Research. Bloomington, IN: Indiana University Press.

Paulson, Ivar. 1971. The Old Estonian Folk Religion. Indiana University Publications, Uralic and Altaic Series 108. Bloomington, IN; Hague: Indiana University; Mouton.

Perrault, Charles. 1999 [1697]. Little Red Riding Hood. - The Classic Fairy Tales. Norton Critical Editions. New York, NY; London: W. W. Norton \& Company, 11-13.

Propp, Vladimir. 2003 [1928]. The Morphology of the Folktale, edited by Louis A. Wagner. Austin, TX: University of Texas Press.

Päär, Piret and Anne Türnpu, comp. 2015 [2005]. Estonian Folktales. The Heavenly Wedding. 2nd revised edn. Tallinn: Varrak.

Salve, Kristi and Vaike Sarv. 1987. Setu lauludega muinasjutud. Tallinn: Eesti Raamat.

Salve, Kristi. 2006. Etnilise ajaloo kajastusi Eesti muinasjuturepertuaaris (Läänemere-balti suhted). - Võim \& kultuur 2, compiled by Mare Kõiva. Tartu: Eesti Kirjandusmuuseum, 327-360.

Toomeos-Orglaan, Kärri. 2016. Mis värvi on muinasjutt? - Mäetagused. Elektrooniline ajakiri 64: $35-56$.

Ussi naine 2014 = Järv, Risto; Kaisa Kulasalu, Mairi Kaasik, Inge Annom, Kärri Toomeos-Orglaan, Reeli Reinaus and Moon Meier, comps. 2014. Ussi naine. Muinasjutte soovide täitumisest. Tartu: EKM Teaduskirjastus.

Vaz da Silva, Francisco. 2000. Cinderella the Dragon Slayer. - Studia mythologica Slavica 3: 187-204.

Vaz da Silva, Fransisco. 2007. Red as Blood, White as Snow, Black as Crow: Chromatic Symbolism of Womanhood in Fairy Tales. - Marvels \& Tales 21 (2): 240-252.

Vaz da Silva, Fransisco. 2015. Fairy-Tale Symbolism. - The Cambridge Companion to Fairy Tales, edited by Maria Tatar. Cambridge: Cambridge University Press, 97-116.

Vaz da Silva, Francisco. 2017. Fairy-Tale Symbolism: An Overview. - Oxford Research Encyclopedia of Literature. DOI: https://doi.org/10.1093/acrefore/9780190201098.013.79.

Verdier, Yvonne. 1997. Little Red Riding Hood in Oral Tradition. - Marvels \& Tales 11 (1-2): 10123. 